\title{
A new antifungal yellow pigment from Aspergillus nishimurae
}

\author{
Tomoo Hosoe ${ }^{1}$, Nobuaki Mori ${ }^{1}$, Kumi Kamano ${ }^{1}$, Takeshi Itabashi ${ }^{1}$, Takeshi Yaguchi ${ }^{2}$ and Ken-ichi Kawai ${ }^{1}$
}

The Journal of Antibiotics (2011) 64, 211-212; doi:10.1038/ja.2010.132; published online 10 November 2010

Keywords: anishidiol; antifungal activity; Aspergillus nishimurae; cytotoxic activity; yellow pigment

The incidence of life-threatening fungal infections has steadily increased in immunocompromised hosts such as HIV-infected persons and cancer and transplant patients. ${ }^{1}$ Invasive pulmonary aspergillosis and Pneumocystis carinii pneumonia are leading causes of death in bone marrow transplant recipients and in HIV-infected patients, respectively. Moreover, resistance to the azoles, which are the most widely used anti-fungal medicines today, is attracting much attention. Therefore, there is a continuing need for new antifungal agents to overcome these fungal diseases. Screening for new antifungal substances from fungal sources was carried out using pathogenic filamentous fungi, Aspergillus fumigatus FrESENIUS IFM41362 and A. niger VAN TIEGHEM IFM41398, and pathogenic yeasts, Candida albicans (ROBIN) BERKHOUT ATCC90028 and Cryptococcus neoformans (SANFelice) VUillemin ATCC90112. The MeOH extract of freshly isolated A. nishimurae IFM58441, cultivated on rice for 21 days at $25^{\circ} \mathrm{C}$, showed antifungal activities against the above four test organisms. The purification of this extract led to the isolation of a new yellow pigment, anishidiol (1) as the antifungal substance, along with 4-hydroxybenzaldehyde, 4-methylbenzylalcohol and monochaetin (2). ${ }^{2}$ The structure elucidation, antifungal activities and cytotoxic activities of $\mathbf{1}$ are described in this paper.

Polished rice $(480 \mathrm{~g})$ was soaked in water for $30 \mathrm{~min}$ and then sterilized with an autoclave. A. nishimurae IFM58441 was cultivated for 14 days in Roux flasks, each containing $140 \mathrm{~g}$ of moist rice. The cultivated rice was extracted with $\mathrm{MeOH}$, and the extract was concentrated in vacuo. The residue was suspended in water and extracted with ethyl acetate. The EtOAc extract (3.6 g) was partitioned between $n$-hexane and $\mathrm{MeCN}$ to yield an $\mathrm{MeCN}$-soluble mixture. The MeCN extract ( $3.0 \mathrm{~g}$ ) was chromatographed using a Sephadex LH-20 column (GE Healthcare UK Ltd., Buckinghamshire, UK; $280 \times 35 \mathrm{~mm}$ (initial condition), solvent system: $n$-hexane- $\mathrm{CHCl}_{3}(1: 4)(180 \mathrm{ml})$, $\mathrm{CHCl}_{3}$-acetone (3:2) $(220 \mathrm{ml}),(1: 4)(200 \mathrm{ml})$, acetone $(200 \mathrm{ml})$ and $\mathrm{MeOH}(500 \mathrm{ml})$ ) to yield 11 fractions. $\mathrm{CHCl}_{3}$-acetone (3:2) eluate was rechromatographed using MPLC with a silica gel (URTRA PACK SI-40B $(300 \times 26 \mathrm{~mm}$, YAMAZEN Corp., Osaka, Japan), $n$-hexaneacetone $(20: 1) 450 \mathrm{ml}$, followed by acetone $150 \mathrm{ml}$ elute; 1 fraction $=15 \mathrm{ml})$ to give monochaetin $(2: 9 \mathrm{mg})$ from fractions $19-20$. Acetone eluate was rechromatographed using HPLC with a silica gel (Inertsil SIL 100A $(250 \times 10 \mathrm{~mm}$, GL Sciences Inc., Tokyo, Japan), $\mathrm{CHCl}_{3}$-acetone $\left.(60: 1)\right)$ to give the yellow compound, anishidiol (1: $3 \mathrm{mg}$ ). 4-Hydroxybenzaldehyde (4 mg) and 4-methylbenzylalcohol $(16 \mathrm{mg})$ were obtained from $\mathrm{MeOH}$ eluate. The spectral data of 2 were identical to those from reports in the literature. ${ }^{2}$

The molecular formula of $\mathbf{1}$ (Figure 1) was confirmed as $\mathrm{C}_{12} \mathrm{H}_{12} \mathrm{O}_{4}$ (seven degrees of unsaturation) by HR EI-MS. Detailed analysis of the ${ }^{1} \mathrm{H}$ - and ${ }^{13} \mathrm{C}-\mathrm{NMR}$ spectrum and heteronuclear single-quantum correlations of 1 revealed the presence of two exchangeable protons $(\delta$ 5.56 and $\delta 12.58)$, two methyl units $(\delta 2.00$ and $\delta 2.11)$, a methylene unit $(\delta$ 5.12), a methine unit $(\delta$ 6.09), a formyl unit $(\delta 10.11)$ and seven quaternary carbons (three of which are oxygenated). These data accounted for the ${ }^{1} \mathrm{H}$ - and ${ }^{13} \mathrm{C}-\mathrm{NMR}$ resonances and required compound 1 to be bicyclic. The HMBC spectrum of 1 was measured for the connectivity of partial units. HMBC correlations from $\mathrm{H}_{3}-11$ to $\mathrm{C}-3, \mathrm{C}-4$, from $\mathrm{H}_{3}-12$ to C-6, C-7 and C-8, from $\mathrm{H}_{2}-1$ to $\mathrm{C}-3, \mathrm{C}-8, \mathrm{C}-9$ and C-10, from $\mathrm{H}-4$ to $\mathrm{C}-3, \mathrm{C}-10$ and $\mathrm{C}-11$, from $\mathrm{H}-13$ to $\mathrm{C}-5$ and $\mathrm{C}-6$, and from $6-\mathrm{OH}$ to $\mathrm{C}-5, \mathrm{C}-6$<smiles>[R]c1cc2ccccc2c(C=O)c1O</smiles>

1

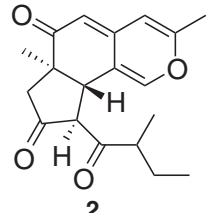<smiles>CCC1=CC2=C(C=O)C(=O)[C@@H](O)[C@@H](O)C2=CO1</smiles>

3
Figure 1 Structures of compounds $\mathbf{1}-\mathbf{3}$.

${ }^{1}$ Faculty of Pharmaceutical Sciences, Hoshi University, Shinagawa-ku, Tokyo, Japan and ${ }^{2}$ Research Center for Pathogenic Fungi and Microbial Toxicoses, Chiba University, Chuo-ku, Chiba, Japan

Correspondence: Dr T Hosoe, Faculty of Pharmaceutical Sciences, Hoshi University, Ebara 2-4-41, Shinagawa-ku, Tokyo 142-8501, Japan.

E-mail: hosoe@hoshi.ac.jp

Received 2 August 2010; revised 16 September 2010; accepted 8 October 2010; published online 10 November 2010 


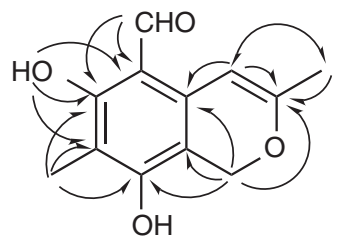

Figure 2 Important HMBC correlations of anishidiol (1).

and C-7 enabled construction of the structure in $\mathbf{1}$ (Figure 2). From the above results, it was determined that the chemical structure of $\mathbf{1}$ is 6,8-dihydroxy-3,7-dimethyl- $1 H$-isochromene-5-carbaldehyde, as shown in Figure 1.

The antifungal activity was determined by the paper disk method ( $8 \mathrm{~mm}$ in diameter), as described in the previous paper. ${ }^{3}$ Compound 1 exhibited antifungal activities against $A$. fumigatus, A. niger, C. albicans and C. neoformans. The diameters of inhibition circles for 1 were 12, 16,21 and $13 \mathrm{~mm}$ at $100 \mu \mathrm{g}$ per disk, respectively. The cytotoxic assay was performed by the modified method as in the previous paper. ${ }^{3}$ Compound 1 was tested for cytotoxic activity against A549 human lung cancer cells, HeLa human cervical cancer cells and LNCap human prostate adenocarcinoma cells. Compound 1 showed no inhibition of this cell proliferation at $100 \mu \mathrm{M}$.

It is likely that compound $\mathbf{1}$ is produced by a reductive aromatization of austdiol (3), which was isolated from $A$. ustus ${ }^{4,5}$ as a gastrointestinal toxin.

The strain IFM58441 was isolated from soil in Cairns, Australia. Colonies on malt extract agar grew fast and abundantly produced grayish green conidiogeneses. The aspergilla were uniseriate and flask-shaped, and the phialides covered the upper half of the vesicle. The conidia were ellipsoidal, almost smooth and $3.5-4 \times 2-3 \mu \mathrm{m}$. The sequence of $\beta$-tubulin gene was equal to that of Neosartorya nishimurae as observed by Takada et al. ${ }^{6}$ However, the strain did not produce ascospores and produced only conidia. Therefore it was identified as $A$. nishimurae.
Anishidiol (1): Yellow crystalline powder, m.p. $136-138^{\circ} \mathrm{C}$ (from acetone), HREI-MS $m / z$ : $220.0748\left[\mathrm{M}^{+}, 220.0735\right.$ for $\left.\mathrm{C}_{12} \mathrm{H}_{12} \mathrm{O}_{4}\right]$. UV $\lambda_{\max }(\mathrm{MeOH}) \mathrm{nm}(\varepsilon): 206$ (4.17), 265 (3.99), 281 (3.99), 312 (4.03), 351(3.82) and 390 (3.54). IR $v_{\max }(\mathrm{KBr}) \mathrm{cm}^{-1} 3394$ $(\mathrm{OH})$ and $1671(\mathrm{C}=\mathrm{O}) .{ }^{1} \mathrm{H}-\mathrm{NMR}\left(\mathrm{CDCl}_{3}\right) \delta 2.00\left(3 \mathrm{H}, \mathrm{s}, \mathrm{H}_{3}-11\right)$, $2.11\left(3 \mathrm{H}, \mathrm{s}, \mathrm{H}_{3}-12\right), 5.12(2 \mathrm{H}, \mathrm{s}, \mathrm{H}-1), 5.56(1 \mathrm{H}, \mathrm{s}, 8-\mathrm{OH}), 6.09(1 \mathrm{H}, \mathrm{s}$, $\mathrm{H}-4), 10.11(1 \mathrm{H}, \mathrm{s}, \mathrm{H}-13), 12.58(1 \mathrm{H}, \mathrm{s}, 6-\mathrm{OH}) .{ }^{13} \mathrm{C}-\overline{\mathrm{N}} \mathrm{MR}\left(\mathrm{CDCl}_{3}\right)$ б 6.9 (C-12), 20.4 (C-11), 63.5 (C-1), 94.8 (C-4), 104.7 (C-10), 106.8 (C-7), 107.7 (C-5), 135.4 (C-9), 156.5 (C-8), 159.3 (C-3), 162.3(C-6) and 191.7 (C-13).

\section{CONFLICT OF INTEREST}

The authors declare no conflict of interest.

\section{ACKNOWLEDGEMENTS}

We thank Dr H Kasai of Hoshi University for MS measurements. This work was supported by the 'Open Research Center' Project from the Ministry of Education, Culture, Sports, Science and Technology, Japan, and by a Grant-inAid for Scientific Research (No. 20590017) from the Japan Society for the Promotion of Science. This study was also partly supported by the Cooperative Research Program of the Research Center for Pathogenic Fungi and Microbial Toxicoses, Chiba University (09-2).

1 Georgopapadakou, N. H. \& Walsh, T. J. Antifungal agents: chemotherapeutic targets and immunologic strategies. J. Antimicrob. Agents Chemother. 40, 279-291 (1996).

2 Steyn, P. S. \& Vieggaar, R. A reinvestigation of the structure of monochaetin, a metabolite of Monochaetiacompta. J. Chem. Soc. Perkin Trans. I, 1986, 1975-1976 (1986).

3 Wakana, D. et al. The cytotoxic and antifngal activities of two new sesquiterpenes, malfilanol A and B, derived from Marblanchea filamentosa. J. Antibiot. 62, 217-219 (2009).

4 Vleggaar, R., Steyn, P. S. \& Nagel, D. W. Constitution and absolute configuration of austdiol, the main toxic metabolite from Aspergillus ustus. J. Chem. Soc. Perkin Trans. I, 1974, 45-49 (1974).

5 Colombo, L., Gennari, C., Ricca, G. S., Scolastico, C. \& Aragozzini, F. Detection of one symmetrical precursor during the biosynthesis of the fungal metabolite austdiol using acetate-1,2- ${ }^{13} \mathrm{C} 2$ and methionine-Me- ${ }^{13} \mathrm{C}$. J. Chem. Soc. Chem. Commun. 1981, 575-576 (1981).

6 Takada, M., Horie, Y. \& Abliz, P. Two new heterothallic Neosartorya from African soil. Mycoscience 42, 361-367 (2001). 